\title{
Faktor yang Mempengaruhi Tax Avoidance dengan Ukuran Perusahaan sebagai Variabel Kontrol
}

\author{
Desy Mariani ${ }^{1)}$ dan Suryani ${ }^{2)}$ \\ Program Studi Akuntansi, Universitas Budi Luhur Jakarta, Indonesia \\ E-Mail : 1)desy.mariani@budiluhur.ac.id ${ }^{2)}$ suryani@budiluhur.ac.id
}

\begin{abstract}
For companies, taxes are costs that reduce profits. The company wants to pay the minimum tax so that the profit earned by the company does not decrease, while from the government side, tax collection is used to finance the implementation of state development. This difference also causes taxpayers to tend to avoid taxes to reduce their tax burden, so that state revenue from the tax sector is still not maximized. This study aims to determine the factors that affect tax avoidance with company size as a control variable. This study uses a sample of trading, service and investment companies in the wholesale and retail trade sub-sector listed on the Indonesia Stock Exchange for the period 2014-2018. The sampling method used in this study was purposive sampling method, where according to the established criteria, 22 companies were obtained and the data used were secondary data. The analysis technique used in this study is multiple linear regression analysis using the Statistical Product and Service Solutions (SPSS) v.20.0 program. The results show that Leverage, Sales Growth and Company Size have a positive effect on tax avoidance, while liquidity and fixed asset intensity have no effect on tax avoidance, thus company size can control Leverage and Sales Growth to influence tax avoidance.
\end{abstract}

Keywords: Tax Avoidance, Fixed Asset Intensity, Sales Growth, Company Size, Financial Ratios

\begin{abstract}
ABSTRAK
Bagi perusahaan, pajak adalah biaya yang mengurangi keuntungan. Perusahaan ingin membayar pajak seminimal mungkin agar keuntungan yang diperoleh perusahaan tidak berkurang, sedangkan dari sisi pemerintah, pemungutan pajak digunakan untuk membiayai pelaksanaan pembangunan negara. Perbedaan ini juga menyebabkan wajib pajak cenderung menghindari pajak untuk mengurangi beban pajaknya, sehingga penerimaan negara dari sektor pajak masih belum maksimal. Penelitian ini bertujuan untuk mengetahui faktor-faktor yang mempengaruhi penghindaran pajak dengan ukuran perusahaan sebagai variabel kontrol. Penelitian ini menggunakan sampel perusahaan perdagangan, jasa dan investasi pada subsektor perdagangan besar dan eceran yang terdaftar di Bursa Efek Indonesia periode 2014-2018. Metode pengambilan sampel yang digunakan dalam penelitian ini adalah metode purposive sampling, dimana berdasarkan kriteria yang telah ditetapkan diperoleh 22 perusahaan dan data yang digunakan adalah data sekunder. Teknik analisis yang digunakan dalam penelitian ini adalah analisis regresi linier berganda dengan menggunakan program Statistical Product and Service Solutions (SPSS) v.20.0. Hasil penelitian menunjukkan bahwa Leverage, Pertumbuhan Penjualan dan Ukuran Perusahaan berpengaruh positif terhadap penghindaran pajak, sedangkan likuiditas dan intensitas aktiva tetap tidak berpengaruh terhadap penghindaran pajak, dengan demikian ukuran perusahaan dapat mengendalikan Leverage dan Pertumbuhan Penjualan untuk mempengaruhi penghindaran pajak.
\end{abstract}

Kata Kunci: penghindaran pajak, intensitas aktiva tetap, pertumbuhan penjualan, ukuran perusahaan, rasio keuangan
Submitted: DESEMBER 2020

Accepted: JUNI 2021

\section{JIAKES}

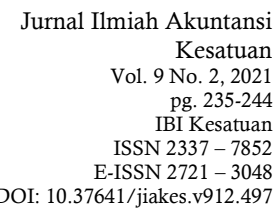


Determinant of tax

Avoidance and

Company Size

$\underline{236}$

\section{PENDAHULUAN}

Salah satu sumber pendapatan bagi negara yaitu berasal dari pajak yang dipungut kepada wajib pajak baik itu wajib pajak orang pribadi, badan usaha maupun bentuk usaha tetap. Pendapatan pajak digunakan oleh negara untuk membiayai pengeluaran negara termasuk membiayai sektor pembangunan. Ketentuan dalam pemungutan pajak telah diatur dalam undang undang oleh pemerintah agar target penerimaan dapat tercapai sesuai dengan yang diinginkan. Direktorat Jenderal Pajak Kementrian Keuangan (DJP Kemenkeu) telah membuat unit transformasi khusus di Direktorat Jenderal Pajak (DJP), dan pada tahun 2014-2015 telah dilakukan pemeriksaan transfer pricing yang cukup signifikan mencapai puluhan triliun yang menjadikan dasar koreksinya. Dalam praktiknya, terdapat perbedaan kepentingan antara perusahaan (wajib pajak) dan pemerintah. Perusahaan menginginkan untuk seminimal mungkin membayar pajak agar laba yang diperoleh perusahaan tidak berkurang, sedangkan dari sisi pemerintah pemungutan pajak digunakan untuk membiayai penyelenggaraan pembangunan negara. Perbedaan tersebut menjadi penyebab wajib pajak lebih cenderung untuk melakukan aksi penghindaran pajak dengan tujuan untuk mengurangi beban pajaknya, hal ini mengakibatkan penerimaan negara yang berasal dari sektor pajak belum secara maksimal diterima.

Salah satu praktik tax avoidance yang dilakukan oleh perusahaan yaitu dengan melakukan praktik transfer pricing untuk meminimalkan pembayaran pajak mereka dengan cara memindahkan keuntungan yang dihasilkan di suatu negara ke negara yang memiliki tarif pajak yang jauh lebih rendah. Pada tahun 2016 terdapat sekitar 2.000 perusahaan multinasional yang beroperasi di Indonesia tidak membayarkan Pajak Penghasilan (PPh) Badan Pasal 25 dan Pasal 29 dengan alasan kerugian, tetapi perusahaan tersebut sebenarnya masih eksis hingga saat ini. Praktik tax avoidance selanjutnya yaitu pada perusahaan bergerak dalam bidang jasa kesehatan yang terafiliasi perusahaan di Singapura yaitu PT Rajawali Nusantara Indonesia (PT RNI). PT RNI merupakan perseroan terbatas namun pendanaan perusahaan bersumber dari utang afiliasi dari pemilik di Singapura. Dengan pendanaan yang bersumber dari hutang ini mengakibatkan adanya beban bunga yang ditanggung perusahaan dan mengurangi pajak. Perusahaan melaporkan kerugian dalam laporan keuangan sehingga tidak ada pajak yang harus dibayarkan ke kas negara.

Berdasarkan penelitian sebelumnya, salah satu faktor yang dapat mempengaruhi tax avoidance adalah likuiditas. Perusahaan dengan rasio likuiditas yang tinggi memiliki kemampuan untuk dapat memenuhi kewajiban jangka pendeknya, hal ini mengindikasikan bahwa perusahaan dalam kondisi yang sehat. Kondisi keuangan perusahaan yang sehat meminimalkan kemungkinan perusahaan untuk melakukan praktik tax avoidance. Begitupun sebaliknya disaat tingkat likuiditas menjadi rendah, maka kecenderungan perusahaan akan berupayan untuk mempertahankan kestabilan arus kasnya sehingga memungkinkan adanya peluang besar untuk dapat terjadi tindakan tax avoidance oleh perusahaan (Suyanto \&Supramono, 2012 dalam Sari, 2019). Penelitian Budianti \& Curry (2018) menyatakan bahwa likuiditas berpengaruh positif terhadap tax avoidance, sedangkan Pasaribu \& Mulyani (2019) menyatakan bahwa likuiditas berpengaruh negatif terhadap tax avoidance.

Faktor berikutnya yaitu leverage. Leverage menggambarkan mampu atau tidaknya suatu perusahaan untuk memenuhi kewajiban keuangannya dalam jangka pendek maupun jangka panjang apabila suatu perusahaan tersebut dilikuidasi. Semakin tinggi hutang perusahaan yang dimiliki maka semakin tinggi pula biaya bunga yang timbul dari hutang tersebut. Dengan adanya biaya bunga akan memberikan pengaruh berkurangnya beban pajak perusahaan. Perusahaan yang memilih kebijakan leverage akan cenderung melakukan tindakan tax avoidance sebagai akibat dari insentif pajak atas beban bunga yang diterima perusahaan untuk meminimalkan beban pajaknya (Ariawan dan Setiawan, 2017). Hal ini sejalan dengan penelitian yang dilakukan Ariawan \& Setiawan (2017) dan 
penelitian Mulyani, Kusmuriyanto \& Suryarini (2017) yang menyatakan bahwa leverage memiliki pengaruh positif terhadap tax avoidance.

Faktor lain yang mempengaruhi Tax Avoidance selanjutnya adalah Intensitas aset tetap dimana gambaran banyaknya investasi terhadap aset tetap yang dimiliki suatu perusahaan. Adanya aset tetap dapat mengurangi pembayaran pajak yang harus dibayar oleh perusahaan karena adanya biaya penyusutan/depresiasi pada aset tetap. Semakin tinggi rasio aset tetap yang dimiliki perusahaan maka semakin besar pula beban depresiasi yang munculyang akan mengurangi laba. Dengan laba perusahaan yang rendah, beban pajak perusahaan juga akan rendah sehingga menjadikan celah perusahaan untuk melakukan tindakan penghindaran pajak. Hasil penelitian Purwanti \& Sugiyarti (2017) yang mengatakan bahwa intensitas aset tetap memiliki pengaruh yang negatif terhadap tax avoidance, sedangkan hasil penelitian Noviyani \& Muid (2019) menyatakan bahwa intensitas aset tetap berpengaruh negatif terhadap tax avoidance.

Faktor selanjutnya yang mempengaruhi Tax Avoidance adalah Pertumbuhan penjualan. Pertumbuhan penjualan memiliki peranan penting dalam manajemen untuk menggambarkan baik atau buruknya tingkat pertumbuhan penjualan suatu perusahaan. Semakin tinggi rasio pertumbuhan penjualan perusahaan maka menandakan kemampuan perusahaan dalam membayar pajaknya, sehingga kemungkinan tindakan penghindaran pajak yang dilakukan oleh perusahaan juga semakin rendah. Hal tersebut tidak sejalan dengan penelitian Nabilla \& Fikri (2018) yang menyatakan bahwa pertumbuhan penjualan berpengaruh positif terhadap tindakan tax avoidance, sedangkan hasil penelitian Hidayat (2018) menyatakan bahwa pertumbuhan penjualan berpengaruh negatif terhadap tax avoidance.

Pada penelitian ini variabel ukuran perusahaan digunakan oleh penulis sebagai variabel kontrol. Menentukan besar atau kecil suatu perusahaan dapat dilihat dari ukuran perusahaan. Dengan adanya ukuran perusahaan kita dapat mengkategorikan perusahaan sebagai perusahaan besar (large firm), perusahaan menengah (medium firm) dan perusahaan kecil (small firm). Salah satu yang dapat dijadikan dasar untuk menentukan ukuran perusahaan yaitu dapat dilihat dari total aset yang dimilikinya. Ukuran perusahaan ini merupakan salah satu cara yang digunakan mengontrol adanya motivasi perusahaan dalam keputusan untuk melakukan atau tidak melakukan penghindaran pajak. Sari dan Martini (2010) menyatakan bahwa perusahaan yang besar cenderung memiliki ETR yang rendah, sebab mereka memiliki sumber daya yang cukup memadai untuk melakukan perencanaan pajak yang baik (political power theory). Dewinta dan Setiawan (2016) dalam penelitiannya menyatakan bahwa ukuran perusahaan berpengaruh positif terhadap tax avoidance ini artinya semakin besar ukuran perusahaan, maka semakin tinggi aktivitas tax avoidance di perusahaan yang disebabkan karena perusahaan dengan jumlah total aset yang relatif besar cenderung lebih mampu dan lebih stabil dalam menghasilkan laba. Menurut Nicodeme (2007), Darmadi (2013) dalam Dewinta dan Setiawan (2016) perusahaan berskala kecil tidak dapat mengelola beban pajaknya secara optimal karena keterbatasan sumber daya yang dimiliki.

Hasil yang beraneka ragam diperoleh dari penelitian sebelumnya yang telah membahas Tax Avoidance. Dalam penelitian ini variabel yang diuji hanya variabel terkait keuangan saja. Tujuan dilakukannya penelitian ini yaitu untuk mengetahui apakah ada pengaruh likuiditas, leverage, Intensitas aset tetap, Pertumbuhan Penjualan terhadap Tax Avoidance dengan Ukuran Perusahaan sebagai variabel kontrol pada perusahaan perdagangan, jasa dan investasi sub sektor perdagangan besar dan eceran yang terdaftar di Bursa Efek Indonesia (BEI). Adapun periode penelitian yang digunakan adalah periode 2014-2018.

\section{Pengembangan Hipotesis}

Pengaruh Likuiditas Terhadap Tax Avoidance. Rasio likuditas yang optimal menunjukan perusahaan dalam keadaan sehat dan mampu untuk memenuhi kewajiban jangka pendeknya tepat waktu. Dengan kemampuan ini perusahaan tidak memiliki kendala dalam pembiayaan operasional dan pemenuhan kewajiban lainnya seperti pajak
Determinant of tax Avoidance and Company Size 
Determinant of tax

Avoidance and

Company Size

238 sehingga kecil kemungkinan perusahaan dengan rasio likuiditas yang baik melakukan praktik tax avoidance. Hasil penelitian yang dilakukan oleh Pasaribu dan Mulyani (2019) menyatakan bahwa likuiditas berpengaruh negatif terhadap tax avoidance. Berdasarkan uraian di atas, dirumuskan hipotesis sebagai berikut: H1: Likuiditas berpengaruh negatif terhadap tax avoidance

Pengaruh Leverage Terhadap Tax Avoidance. Leverage merupakan rasio yang mengukur kemampuan perusahaan dalam memenuhi kewajiban keuangan perusahaan baik jangka pendek maupun jangka panjang. Dalam Ariawan dan Setiawan (2017) menyatakan bahwa semakin tinggi rasio leverage suatu perusahaan, maka semakin tinggi jumlah pendanaan dari hutang pihak ketiga yang digunakan perusahaan dan semakin tinggi pula biaya bunga yang timbul dari hutang tersebut. Beban bunga yang semakin tinggi akan memberikan pengaruh berkurangnya beban pajak perusahaan. Perusahaan akan memilih kebijakan leverage untuk mendapatkan insentif pajak yang memanfaatkan beban bunga untuk memperkecil beban pajaknya yang menjadikan celah untuk melakukan penghindaran pajak. Dengan demikian perusahaan dengan rasio leverage yang tinggi akan cenderung melakukan tindakan penghindaran pajak, begitupun sebaliknya jika rasio leverage perusahaan rendah akan mengurangi tingkat penghindaran pajak. Hasil penelitian yang dilakukan oleh Ariawan dan Setiawan (2017) dan Mulyani, Kusmuriyanto dan Suryarini (2017) menyatakan bahwa leverage memiliki pengaruh positif terhadap tax avoidance. Berdasarkan uraian di atas, dirumuskan hipotesis sebagai berikut: H2: Leverage berpengaruh positif terhadap tax avoidance

Pengaruh Intensitas Aset Tetap Terhadap Tax Avoidance. Intensitas aset tetap merupakan proporsi di mana dalam aset tetap terdapat pos bagi perusahaan untuk menambahkan beban yaitu beban penyusutan yang ditimbulkan oleh aset tetap sebagai pengurang penghasilan, jika aset tetap semakin besar maka laba yang dihasilkan akan semakin kecil, karena adanya beban depresiasi yang terdapat dalam aset tetap yang dapat mengurangi laba perusahaan (Mulyani, 2014 dalam Sundari dan Apriliana, 2017). Semakin tinggi aset tetap yang dimiliki perusahaan maka semakin besar pula beban penyusutan yang dikurangkan sehingga dasar untuk menghitung pajak semakin kecil. Perhitungan pajak perusahaan yang kecil menjadikan celah perusahaan untuk melakukan tindakan penghindaran pajak. Jadi semakin tinggi intensitas aset tetap yang dimiliki oleh perusahaan maka semakin besar tindakan penghindaran pajak yang dilakukan oleh perusahaan. Hasil penelitian yang dilakukan oleh Noviyani dan Muid (2019) menyatakan bahwa intensitas aset tetap berpengaruh positif terhadap tax avoidance. Berdasarkan uraian di atas, dirumuskan hipotesis sebagai berikut: H3: Intensitas Aset Tetap berpengaruh positif terhadap tax avoidance

Pengaruh Pertumbuhan Penjualan Terhadap Tax Avoidance. Pertumbuhan penjualan merupakan perhitungan kenaikan atau penurunan pejualan dari tahun ke tahun. Perusahaan dengan tingkat pertumbuhan penjualan yang tinggi maka akan memperoleh laba yang juga tinggi. Dalam rasio pertumbuhan penjualan ini perusahaan bisa melihat bagaimana perkembangan bisnis mereka dari tahun ke tahun (Dewinta dan Setiawan, 2016). Pertumbuhan penjualan perusahaan yang tinggi akan selalu diikuti dengan peningkatan laba yang menyebabkan meningkat pula tarif pajak suatu perusahaan. Semakin tinggi rasio pertumbuhan penjualan perusahaan maka semakin tinggi pula kemampuan perusahaan dalam membayar pajaknya sehingga semakin rendah tindakan penghindaran pajak yang dilakukan oleh perusahaan tersebut. Hasil penelitian yang dilakukan oleh Hidayat (2018) menyatakan bahwa pertumbuhan penjualan berpengaruh negatif terhadap tax avoidance. Berdasarkan uraian di atas, dirumuskan hipotesis sebagai berikut: H4: Pertumbuhan Penjualan berpengaruh negatif terhadap tax avoidance

Ukuran Perusahaan dapat mengontrol Likuiditas, Leverage, Intensitas Aset Tetap dan Pertumbuhan Penjualan Terhadap Tax Avoidance. Ukuran suatu perusahaan dapat dilihat dari aset yang dimilikinya. Semakin meningkat aset yang dimiliki maka kekuatan perusahaan untuk melakukan perjualan semakin besar, dengan angka peningkatan nilai penjualan yang tinggi dapat mempengaruhi besarnya laba yang dapat diperoleh 
perusahaan. Menurut Sari dan Martani (2010) semakin besar perusahaan maka akan semakin rendah ETR yang dimilikinya. Hasil penelitian Rusydi dan Veronika (2013) menyetakan bahwa ukuran perusahaan tidak berpengaruh terhadap aggresive tax avoidance di Indonesia, yang artinya bahwa perilaku perusahaan- perusahaan di Indonesia untuk melakukan aggresive tax avoidance tidak dipengaruhi oleh besar kecilnya perusahaan. H5: Ukuran perusahaan dapat mengontrol Likuiditas, leverage, Intensitas Aset Tetap, Pertumbuhan Penjualan berpengaruh secara positif terhadap tax avoidance.

\section{METODE PENELITIAN}

Populasi sektor perusahaan dalam penelitian ini yaitu perusahaan perdagangan, jasa dan investasi sub sektor perdagangan besar dan perdagangan eceran yang terdaftar di Bursa Efek Indonesia (BEI) pada periode tahun 2014 sampai dengan tahun 2018. Metode yang digunakan dalam pengambilan sampel penelitian ini yaitu teknik purposive sampling, yaitu pengambilan sampel berdasarkan kriteria-kriteria yang telah ditentukan oleh peneliti. Pengujian hipotesis dalam penelitian dini dilakukan dengan menggunakan analisis regresi linier berganda sebagai berikut:

\section{Persamaan 1}

Persamaan 2

$$
\begin{gathered}
Y=\alpha+\beta_{1} X_{1}+\beta_{2} X_{2}+\beta_{3} X_{3}+\beta_{4} X_{4}+e \\
Y=\alpha+\beta_{1} X_{1}+\beta_{2} X_{2}+\beta_{3} X_{3}+\beta_{4} X_{4}+\beta_{5} X_{5} e
\end{gathered}
$$

Keterangan:

$$
\mathrm{Y}=\operatorname{ETR}(\text { Tax Avoidance })
$$

$\mathrm{a}=$ Konstanta

$\beta_{1,} \beta_{2}, \beta_{3,} \beta_{4,} \beta_{5}=$ Koefisien regresi variabel masing-masing independen

$\mathrm{X}_{1}, \mathrm{X}_{2}, \mathrm{X}_{3}, \mathrm{X}_{4}, \mathrm{X}_{5}=$ Variabel independen yang mempunyai nilai tertentu dalam penelitian

$\mathrm{X}_{1}=$ Current Ratio (Likuiditas)

$\mathrm{X}_{2}=$ Debt to Equity Ratio (Leverage)

$\mathrm{X}_{3}=$ Intensitas Aset Tetap

$\mathrm{X}_{4}=$ Pertumbuhan penjualan

$\mathrm{X}_{5}=$ Ukuran Perusahaan

$\mathrm{e}=$ Standard Error

Analisis data dilakukan untuk menjawab semua pertanyaan penelitian dalam penelitian ini, hipotesis diuji dengan menggunakan analisis regresi linier berganda. Analisis dilakukan dengan bantuan program aplikasi IBM Statistical Product and Service Solutions(SPSS) versi 20.0.

\section{HASIL DAN PEMBAHASAN \\ Uji Kualitas Data}

Hasil uji normalitas Kolmogorov-Smirnov berdasarkan data didapatkan hasil nilai Asymp. Sig (2-tailed) persamaan 1 sebesar 0,120 dan persamaan 2 sebesar 200. Dari kedua nilai Asymp Sig (2-tailed) lebih besar dari signifikansi sebesar 0,05, sehingga dapat disimpulkan bahwa data yang diuji berdistribusi normal. Hasil Uji multikolinearitas menunjukkan semua variabel masing-masing yaitu variabel likuiditas, leverage, intensitas aset tetap, pertumbuhan penjualan dan ukuran perusahaan memiliki nilai yang lebih dari 0,1, dan untuk nilai VIF (Variance Inflation Factor) pada setiap variabel penelitian ini memiliki nilai kurang dari angka 10, sehingga hasil dalam penelitian ini dapat disimpulkan tidak terjadi permasalahan multikolinearitas pada model regresi ini.

Uji heteroskedastisitas dalam penelitian ini menggunakan uji gletser dimana uji ini untuk menentukan gejala heteroskedastisitas variabel-variabelnya. Berdasarkan hasil uji gletser dari dua persamaan tersebut untuk kelima variabel diperoleh nilai $\mathrm{p}$ value pada
Determinant of tax Avoidance and Company Size 
Determinant of tax Avoidance and Company Size

240 kolom Sig. memiliki nilai lebih dari signifikansi 0,05 , sehingga datadalam penelitian ini disimpulkan tidak tedapat masalah heteroskedastisitas.

Model regresi yang baik adalah model regresi yang tidak memiliki masalah autokorelasi. Pengujian autokorelasi disini memiliki tujuan untuk menguji apakah terdapat korelasi antara kesalah pengganggu pada periode $t$ dengan kesalahan pengganggu periode t-1 (sebelumnya) (Ghozali, 2014). Berdasarkan hasil uji autokorelasi dalam penelitian dini didapatkan nilai Durbin Watson sebesar 1,949 untuk persamaan 1 dan 1,895 untuk Persamaan 2, maka dapat disimpulkan bahwa hasil penelitian ini dapat disimpulkan bahwa tidak terdapat autokolerasi pada model regresi ini.

\section{Uji Koefisien Determinasi (Adjusted $\boldsymbol{R}^{2}$ )}

Hasil uji koefisien determinasi dalam penelitian ini diperoleh hasil perhitungan Adjusted $R$-Squares sebesar 0,020 atau 2\%. Hal ini berarti persentase kontribusi variabel antara likuiditas, leverage, intensitas aset tetap dan pertumbuhan penjualan terhadap tax avoidance sebesar $2 \%$. Sedangkan sisanya yaitu 98\% (100\% - 2\%) dalam penelitian ini dipengaruhi oleh variabel-variabel lain yang tidak dijelaskan. Sedangkan untuk persamaan 2 diperoleh hasil perhitungan Adjusted R-Squares sebesar 0,047 atau 4,7\%. Hal ini berarti persentase kontribusi variabel antara likuiditas, leverage, intensitas aset tetap, pertumbuhan penjualan dan ukuran perusahaan terhadap tax avoidance sebesar $4,7 \%$. Sedangkan sisanya yaitu $95,3 \%(100 \%-4,7 \%)$ dalam penelitian ini dipengaruhi oleh variabel-variabel lain yang tidak dijelaskan.

\section{Uji Kelayakan Model (Uji F)}

Uji statistik $\mathrm{F}$ ini untuk mengetahui ada atau tidaknya pengaruh secara bersamaan (simultan) variabel-variabel independen (bebas) terhadap variabel dependen (terikat). Berdasarkan hasil persamaan 1 dengan hasil perhitungan antara $F_{\text {hitung }}$ dan $F_{\text {tabel }}$ menjelaskan bahwa $F_{\text {hitung }} 3,259>F_{\text {tabel }} 2,481$. Selain itu jika dilihat dari nilai signifikansi yang dihasilkan adalah sebesar 0,015 lebih kecil dari angka sig yaitu 0,05, sedangkan perhitungan persamaan 2 dengan hasil perhitungan antara $F_{\text {hitung }}$ dan $F_{\text {tabel }}$ menjelaskan bahwa $F_{\text {hitung }} 4,371>F_{\text {tabel }} 2,481$. Selain itu jika dilihat dari nilai signifikansi yang dihasilkan adalah sebesar 0,001 lebih kecil dari angka sig yaitu 0,05, sehingga hasil dari kedua persamaan ini disimpulkan bahwa model regresi ini layak digunakan untuk menganalisis pengaruh likuiditas, leverage, intensitas aset tetap, pertumbuhan penjualan dan ukuran perusahaan terhadap tax avoidance.

\section{Uji Hipotesis (Uji t)}

Uji t bertujuan untuk melihat apakah variabel independen secara individual memiliki pengaruh terhadap variabel dependen (Ghozali, 2014). Uji t digunakan untuk melihat apakah hipotesis yang diajukan dapat diterima atau ditolak. Dasar pengambilan keputusannya yaitu jika nilai signifikansi $\mathrm{t} \leq 0,05$ maka hipotesis diterima artinya variabel independen $(\mathrm{X})$ dalam penelitian ini secara individual memiliki pengaruh terhadap variabel dependen (Y), begitu juga sebaliknya. Hasil uji t dilihat pada tabel dibawah berikut ini:

Tabel 1 Uji t

\begin{tabular}{|l|c|c|c|c|}
\hline \multirow{2}{*}{\multicolumn{1}{|c|}{ Variabel }} & \multicolumn{2}{c|}{ Uji t } & \multicolumn{2}{c|}{ Sig } \\
\cline { 2 - 5 } & Persamaan 1 & Persamaan 2 & Persamaan 1 & Persamaan 2 \\
\hline Likuiditas & 0,412 & 0,548 & 0,682 & 0,585 \\
\hline Leverage & 2,299 & 2,391 & 0,024 & 0,019 \\
\hline Intensitas Aset Tetap & 0,033 & 0,275 & 0,973 & 0,784 \\
\hline Pertumbuhan Penjualan & 3,122 & 3,031 & 0,002 & 0,003 \\
\hline Ukuran Perusahaan & & 2,807 & & 0,006 \\
\hline
\end{tabular}

Sumber: Data diolah dengan IBM SPSS versi 20

Berdasarkan hasil uji t pada tabel diatas, dapat disimpulkan bahwa variabel likuiditas (CR) dan intensitas aset tetap tidak berpengaruh terhadap tax avoidance sedangkan Leverage, Pertumbuhan Penjualan dan ukuran perusahaan berpengaruh positif dan signifikan terhadap tax avoidance. 
Interpretasi Hasil Penelitian

Pengaruh Likuiditas Terhadap Tax Avoidance. Hasil pengujian hipotesis menunjukkan bahwa likuiditas tidak berpengaruh terhadap tax avoidance. Perusahaan mempertahankan likuditas sangatlah penting, ini menunjukkan bahwa keuangan perusahaan dalam kondisi yang sehat dan tidak memiliki masalah mengenai arus kas akan mampu menanggung biaya-biaya yang muncul seperti pajak, dalam hal ini memungkinan perusahaan tidak perlu melakukan penghindaran pajak. Hasil penelitian ini tidak sejalan dengan penelitian yang dilakukan oleh Budianti dan Curry (2018) yang menyatakan bahwa likuiditas memiliki pengaruh positif terhadap tax avoidance dan juga penelitian yang dilakukan oleh Pasaribu dan Mulyani (2019) yang menyatakan bahwa likuiditas memiliki pengaruh negatif terhadap tax avoidance. namun sejalan dengan hasil penelitian yang dilakukan oleh Ekaputra dan Widyasari (2019) yang menyatakan bahwa likuiditas tidak berpengaruh terhadap tax avoidance.

Pengaruh Leverage Terhadap Tax Avoidance. Hasil pengujian hipotesis menunjukkan bahwa leverage berpengaruh positif terhadap tax avoidance. Hal ini berarti bahwa Perusahaan yang menggunakan utang untuk membiayai aktivitas operasionalnya akan mengakibatkan munculnya beban bunga akibatnya laba yang diperoleh perusahaan akan berkurang sehingga pajak yang harus dibayar perusahaan akan menjadi lebih rendah jadi bukan dengan sengaja melakukan penghindaran pajak. Beban pajak yang rendah akan berdampak pada kecenderungan penurunan upaya penghindaran pajak. Hasil penelitian ini sejalan dengan penelitian Ariawan dan Setiawan (2017) dan penelitian Mulyani, Kusmuriyanto dan Suryawini (2017) yang menyatakan bahwa leverage memiliki pengaruh positif terhadap tax avoidance.

Pengaruh Intensitas Aset Tetap Terhadap Tax Avoidance. Berdasarkan hasil penelitian menunjukkan intensitas asset tetap tidak berpengaruh terhadap tax avoidance. Hal ini menunjukkan Tinggi rendahnya tingkat intensitas aset tetap yang dimiliki perusahaan tidak mampu mempengaruhi dalam melakukan tindakan tax avoidance yang dilakukan oleh perusahaan, karena perusahaan belum mampu memanfaatkan beban depresiasi untuk mengurangi laba bersih perusahaan. Apabila perusahaan lebih mementingkan beban depresiasi sebagai pengurang tanggungan pajak, hal ini menjadi tidak baik bagi perusahaan karena perusahaan akan mendapatkan kerugian yang sangat besar. Aset tetap yang sesuai dengan kebutuhan perusahaan akan lebih menguntungkan perusahaan dalam melakukan aktivitas perusahaan, dan meningkatkan laba bersih dan akan berdampak pada kecenderungan penurunan upaya penghindaran pajak. Temuan penelitian ini mendukung penelitian Febrianti dan Puspita (2017), Adisamartha dan Noviari (2015) yang menyatakan bahwa aset tetap tidak berpengaruh signifikan terhadap tax avoidance yang artinya perusahaan dengan tingkat aset tetap tinggi tidak mampu memanfaatkan beban depresiasi untuk mengurangi laba bersih. Penggunaan aset tetap untuk membantu operasional perusahaan tersebut mampu meningkatkan operasional perusahaan dan meningkatkan laba bersih lebih tinggi dibandingkan beban depresiasi yang dibebankan pada aset tetap. Namun, temuan penelitian ini tidak mendukung penelitian yang dilakukan oleh Noviyani dan Muid (2019) yang menyatakan bahwa intensitas aset tetap berpengaruh positif terhadap tax avoidance. Juga penelitian yang dilakukan oleh Purwanti dan Sugiyarti (2017) yang menyatakan bahwa intensitas aset tetap berpengaruh negatif terhadap tax avoidance.

Pengaruh Pertumbuhan Penjualan Terhadap Tax Avoidance. Hasil hipotesis menunjukkan bahwa pertumbuhan penjualan berpengaruh positif dan signifikan terhadap tax avoidance. Hal ini menunjukkan bahwa Perusahaan mempunyai kinerja yang baik selain itu laba yang dihasilkan juga mengalami peningkatan dan perusahaan mampu membayar pajak sesuai dengan besar pajak yang tertanggung. Selain itu pengawasan terhadap perusahaan dengan tingkat penjualan yang tinggi juga lebih diperketat terutama dalam hal perpajakan. Hasil penelitian ini sejalan dengan penelitian yang dilakukan oleh Nabilla dan Fikri (2018) menyatakan bahwa pertumbuhan penjualan memiliki pengaruh positif dan signifikan terhadap tax avoidance dan tidak sejalan dengan penelitian yang
Determinant of tax

Avoidance and Company Size 
Determinant of tax Avoidance and Company Size

dilakukan oleh Hidayat (2018) yang menyatakan bahwa pertumbuhan penjualan berpengaruh negatif terhadap tax avoidance.

Ukuran Perusahaan dapat mengontrol Leverage, dan Pertumbuhan Penjualan untuk mempengaruhi Tax Avoidance. Hasil hipotesis menunjukkan bahwa Ukuran Perusahaan sebagai variabel kontrol berpengaruh Positif dan signifikan terhadap tax avoidance. Hal ini menunjukkan bahwa Besarnya aset yang dimiliki perusahaan tidak dimanfaatkan untuk melakukan penghindaran pajak tetapi aset perusahaan digunakan untuk meningkatkan operasional perusahaan tersebut sehingga menimbulkan beban lain-lain yang mengurangi beban pajak yang dibayarkan. Perusahaan juga tidak selalu dapat menggunakan power yang dimilikinya untuk melakukan perencanaan pajak karena adanya batasan berupa kemungkinan menjadi sorotan dan sasaran dari keputusan regulator (political cost theory). Sehingga Ukuran perusahaan akan mempengaruhi tindakan manajemen dalam melakukan penghindaran pajak (tax avidance). Hal ini menjelaskan semakin besar perusahaan maka semakin akan semakin tinggi penghindaran pajaknya. Hasil pengujian ini sesuai dengan penelitian yang dilakukan Hanum dan Zulaikha (2013) yang menjelaskan bahwa semakin besar perusahaan maka akan berdampak dengan tarif pajak perusahaan. Dalam penelitian ini terdapat satu 3 factor yang mempengaruhi tax avoidance, yaitu Leverage, Pertumbuhan Penjualan dan ukuran perusahaan sebagai variabel kontrol, seperti yang digunakan oleh Minnick dan Noga (2010). Hasil penelitian ini menemukan bahwa ukuran perusahaan berpengaruh positif signifikan terhadap Tax Avoidance.

\section{PENUTUP}

Penelitian ini bermaksud untuk melakukan pengujian secara empiris mengenai Faktor faktor yang mempengaruhi tax avoidance dengan ukuran perusahaan sebagai variabel kontrol pada perusahaan perdagangan, jasa dan investasi sub sektor perdagangan besar dan perdagangan eceran yang terdaftar di Bursa Efek Indonesia (BEI) pada periode 2014 sampai dengan 2018. Setelah dilakukan penelitian ini, maka diperoleh kesimpulan sebagai berikut:

a. Likuiditas tidak berpengaruh terhadap tax avoidance.

b. Leverage berpengaruh positif dan signifikan terhadap tax avoidance.

c. Intensitas aset tetap tidak berpengaruh terhadap tax avoidance.

d. Pertumbuhan penjualan berpengaruh positif dan signifikan terhadap tax avoidance.

e. Ukuran Perusahaan berpengaruh positif dan signifikan terhadap tax avoidance

f. Ukuran Perusahaan dapat mengontrol Leverage, dan Pertumbuhan Penjualan untuk mempengaruhi Tax Avoidance

\section{DAFTAR PUSTAKA}

Adisamartha, Ida Bagus Putu Fajar., \& Naniek Noviari. (2015). Pengaruh Likuiditas, Leverage, Intensitas Persediaan dan Intensitas Aset Tetap pada Tingkat Agresivitas Wajib Pajak Badan. E-Jurnal Akuntansi Universitas Udayana, 13 (3), 973-1000. 2015

Akbar, B., Aziz, H.A., Djazuli, A., Kowi, M. and Amyar, F., 2018, February. Performance Effectiveness Measurement of Village Funding Management Using Fuzzy Inference System (FIS) Method. In Conference Proceedings Jakarta Indonesia, ICABE 2018.

Anwar, A.D. and Amyar, F., 2020. Analisis Faktor-Faktor Yang Mempengaruhi Kualitas Audit Internal Dalam Pengambilan Keputusan Laporan Keuangan Pada PT Damar Bandha Jaya Bogor. Jurnal Ilmiah Akuntansi Kesatuan, 8(1), pp.87-96.

Ariawan, I Made Agus Riko. \& Setiawan, Putu Ery. (2017). Pengaruh Dewan Komisaris Independen, Kepemilikan Institusional, Profitabilitas dan Leverage Terhadap Tax Avoidance. E-Jurnal Akuntansi Universitas Udayana, 18 (3), 1831-1859. 2017

Budianti, Shinta. \& Curry, Khristina. (2018). Pengaruh Profitabilitas, Likuiditas, Dan Capital Intensity Terhadap Penghindaran Pajak (Tax Avoidance). Jurnal Keuangan FEB Universitas Trisakti, 1205-1209. 2018 
Budiman, M. A., \& Amyar, F. (2021). The effect of audit opinions, implementation of audit recommendations, and findings of state losses on corruption levels in the ministries and institutions of the Republic of Indonesia. Jurnal Tata Kelola Dan Akuntabilitas Keuangan Negara, 7(1), 113-129. https://doi.org/10.28986/jtaken.v7i1.471

Dewinta, Ida. A. \& Setiawan, Putu. E. (2016). Pengaruh Ukuran Perusahaan, Umur Perusahaan, Profitabilitas, Leverage, dan Pertumbuhan Penjualan Terhadap Tax Avoidance. E-Jurnal Akuntansi Universitas Udayana, 14(3), 1584-1613. 2016

Ekaputra dan Widyasari. (2019) Faktor-Faktor Yang Mempengaruhi Penghindaran Pajak Perusahaan Properti Dan Real Estate, Jurnal Multiparadigma Akuntansi, Volume I No. 3/2019 Hal: 937-945 2019

Emmy, S., Purba, J.H.V. and Rangga, M., 2006. Pengaruh endoser pada media iklan televise terhadap citra produk. Journal Ekonomi dan Bisnis, 6(2), pp.99-103.

Febrianti dan Puspita (2017). Faktor-faktor yang Memengaruhi Penghindaran Pajak Pada Perusahaan Manufaktur Di Bursa Efek Indonesia. Jurnal Bisnis dan Akuntansi. Vol .19. No.01.ISSN: 1410-9875.2017

Fahmi, Irham. (2014). Analisis Kinerja Keuangan. (Bandung: Alfabeta 2014).

Ghozali, Imam. (2014). Ekonometrika: Teori, Konsep dan Aplikasi dengan IBM SPSS 22. (Semarang: Badan Penerbit Universitas Diponegoro 2014).

Hanum, Hashemi Rodhian dan Zulaikha. 2013. Pengaruh Karakteristik Corporate Governance Terhadap Effective Tax Rate. Diponegoro Journal Of Accounting,Vol. 2 (2), 1-10. 2013

Hidayat, Wastam Wahyu. (2018). Pengaruh Profitabilitas, Leverage Dan Pertumbuhan Penjualan Terhadap Penghindaran Pajak Studi Kasus Perusahaan Manufaktur Di Indonesia. Jurnal Riset Manajemen dan Bisnis (JRMB) Fakultas Ekonomi UNIAT, 3 (1), 19-26. 2018

Kasmir. (2016). Analisis Laporan Keuangan. (Jakarta: PT Raja Grafindo Persada. 2016)

Minnick dan Noga (2010) Minnick dan Noga.2010."Docorporate governance characteristics influence tax management?". Journal of Corporate Finance, Vol. 16, hal. 703-718. 2010

Muanas, M. and Wijayantri, A.C., 2010. Evaluasi Atas Penerapan Sistem Online Payment Point Pos (SOPPOS) Dalam Kaitannya Dengan Efisiensi Kegiatan Operasional Pada PT Pos Indonesia (Persero). Jurnal Ilmiah Ranggagading (JIR), 10(1), pp.28-31.

Mulyana, M., 2012. Consumer Behaviour: Sukses Dengan Memahami Konsumen.

Nabilla, Safirra Salsa. \& Fikri, Imam Zul. (2018). Pengaruh Risiko Perusahaan, Leverage (Debt To Equity Ratio) Dan Pertumbuhan Penjualan Terhadap Penghindaran Pajak (Tax Avoidance) Pada Perusahaan Manuufaktur Subsektor Makanan \& Minuman Yang Terdaftar di BEI Tahun 2014-2017. Jurnal Keuangan FEB Universitas Trisakti, 1179-1182. 2018

Noviyani, Espi. \& Muid, Dul. (2019). Pengaruh Return On Assets, Leverage, Ukuran Perusahaan, Intensitas Aset Tetap dan Kepemilikan Institusional Terhadap Penghindaran Pajak. Diponegoro Journal Of Accounting, 8(3), 1-11. 2019

Pasaribu, David Malindo dan Mulyani Susi Dwi, (2019). Pengaruh Leverage dan Liquidity Terhadap Tax Avoidance Dengan Inventory Intensity Sebagai Variabel Moderasi Jurnal Akuntansi Maranatha Vol 11, Nomor 2, November 2019, pp 211-217

Pasaribu, David Malindo. (2017). Pengaruh Leverage dan Liquidity Terhadap Tax Avoidance Dengan Inventory Intensity Sebagai Variabel Moderasi. Jurnal Akuntansi Maranatha, 11(2), 211-217. 2017

Pohan, Chairil Anwar. (2014). Pengantar Perpajakan: Teori dan Konsep Hukum Pajak. (Jakarta: Mitra Wacana Media. 2014)

Purba, J.H.V., 2001. Keragaan Kelapa Sawit Indonesia Ditinjau dari Jenis Pengusahaan dan Wilayah Produksi.
Determinant of tax Avoidance and Company Size 
Determinant of tax Avoidance and Company Size

244
Purwanti, Shinta Meilina., \& Sugiyarti, Listya. (2017). Pengaruh Intensitas Aset Tetap, Pertumbuhan Penjualan dan Koneksi Politik Terhadap Tax Avoidance. JRAK Universitas Pendidikan Indonesia, 5 (3), 1625-1642. 2017

Rahmawati, Dwi dan Pinem, Br. Dahlia. 2015. "Pengaruh Profitabilitas, Leverage, dan Ukuran Perusahaan terhadap Nilai Perusahaan". Equity, Vol. 18, No. 1, pp. 1-18 2015

Sari, Lusi Indah. (2019). Analisis Pengaruh Return On Assets, Debt To Equity Ratio, Debt To Assets Ratio, Current Ratio dan Financial Lease Terhadap Tax Aoidance Pada Perusahaan Manufaktur Yang Terdaftar di BEI Periode 2012-2017. Jurnal Sains, Akuntansi dan Manajemen, 1(1), 301-336. 2019

Sari, Dewi Kartika., \& Martini, Dwi. 2010. Kepemilikan Keluarga, Corporate Governance dan Tindakan Pajak Agresif. Journal Ifrs Convergence and Application Faculty of Economics Universitas Indonesia.

Stella, L.A. and Puspitasari, R., 2020. Analysis of Bank Rating with RGEC Method. Atlantis Press, 143, pp.240-245.

Sulistiono, S. and Mulyana, M., 2020. Pelatihan Pengembangan Merek Dan Kemasan Bagi UMKM Kota Bogor. Jurnal Abdimas Dedikasi Kesatuan, 1(2), pp.87-96.

Sundari, Novi. \& Apriliana, Vita. (2017). Pengaruh Konservatisme Akuntansi, Intensitas Aset Tetap, Kompensasi Rugi Fisikal dan Corporate Governance Terhadap Tax Avoidance. JRAK, 8 (1), 85-109. 2017

Supriadi, Y. and Fazriani, F., 2011. Pengaruh Modal Kerja Terhadap Tingkat Likuiditas Daan Profitabilitas PT timah, Tbk dan PT Antam. Tbk. Bogor.

Tristianto, Deny. \& Oktaviani, Rachmawati Meita. (2016). Faktor-Faktor yang Mempengaruhi Tax Avoidance dengan Leverage Sebagai Variabel Mediasi. Jurnal Akuntansi, Keuangan dan Perbankan Universitas Stikubank Semarang, 5 (1), 65 81.2016 